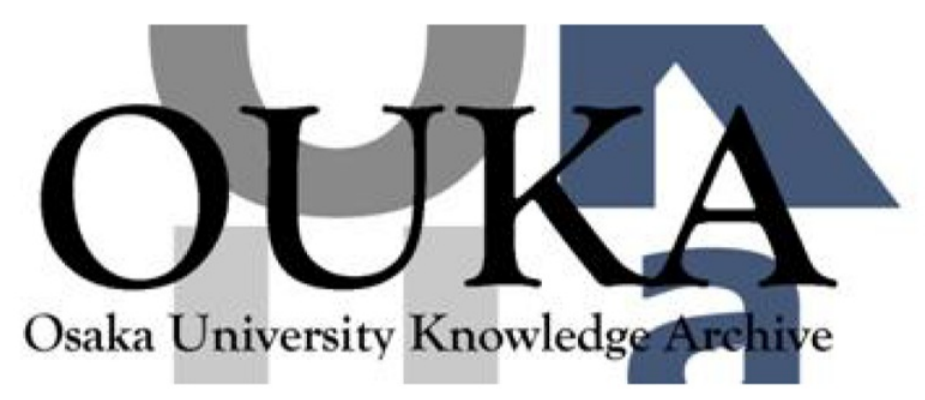

\begin{tabular}{|c|l|}
\hline Title & $\begin{array}{l}\text { Photochemistry of N-Alk-4-enyl- and N-Alk-5- } \\
\text { eny L-phthalimides : Two Different Types of } \\
\text { Cyclization Reaction }\end{array}$ \\
\hline Author(s) & $\begin{array}{l}\text { Maruyama, Kazuhiro; Ogawa, Takuj i ; Kubo, Yasuo } \\
\text { et al. }\end{array}$ \\
\hline Citation & $\begin{array}{l}\text { JOURNAL OF THE CHEMICAL SOCIETY-PERKIN } \\
\text { TRANSACTIONS 1. 10 p. 2025-p. 2031 }\end{array}$ \\
\hline Issue Date & 1985 \\
\hline oaire:version & VoR \\
\hline URL & https://hdl. handle. net/11094/3211 \\
\hline rights & \\
\hline Note & \\
\hline
\end{tabular}

Osaka University Knowledge Archive : OUKA

https://ir. Library. osaka-u. ac. jp/

Osaka University 


\title{
Photochemistry of $\mathbf{N}$-Alk-4-enyl-and $\boldsymbol{N}$-Alk-5-enyl-phthalimides: Two Different Types of Cyclization Reaction
}

\author{
Kazuhiro Maruyama and Takuji Ogawa \\ Department of Chemistry, Faculty of Science, Kyoto University, Kyoto 606, Japan \\ Yasuo Kubo* and Takeo Araki \\ Department of Chemistry, Faculty of Science, Shimane University, Matsue, Shimane 690, Japan
}

Photochemical reactions of $N$-alk-4- and -5-enylphthalimides (1a-e) have been investigated. In the photolyses of acetonitrile solutions of $(1 \mathrm{a}-\mathrm{e})$, intramolecular cyclization reactions accompanying $\mathrm{C}(=\mathrm{O})-\mathrm{N}$ bond cleavage to give $(2 \mathrm{a}-\mathbf{e})$ were generally predominant, together with intramolecular hydrogen abstraction in some cases. Photolyses of cis-and trans- $N$-hex-4-enylphthalimides [cis-(1e) and trans-(1e)] in acetonitrile solutions showed stereospecific cyclization reactions; irradiation of cis(1e) gave cis-(2e) and that of trans-(1e) gave trans-(2e) selectively with low conversion. In methanol (1d), which has a vinyl ether moiety, gave different types of cyclization product: namely, (8a) and (9a), methanol-incorporated products probably resulting from an intramolecular electron transfer process.

The photochemistry of imides has been the subject of intensive investigation. With an interest in the photochemical reactions of imides with olefins, we found that in the photolysis of alicyclic imides with olefins, oxetane formation typically occurred, an example of normal $n \pi^{*}$ carbonyl photo-reactivity. ${ }^{2}$ In contrast, the photo-reactions of phthalimides with olefins are quite different. Thus, the photo-reactions of $\mathrm{N}$-alk-2-enylphthalimides in alcohols gave products in which solvent-incorporated cyclization and elimination had occurred, probably via intramolecular electron transfer from the olefinic moiety to the excited phthalimide moiety. ${ }^{3}$ Further, photolysis of $N$-alkenylphthalimides having a more remote alkenyl double bond generally gave solvent-incorporated medium-sized cyclic to macrocyclic cyclization products. ${ }^{4}$ Thus, the solvent-incorporated cyclization reaction seems to represent a more typical reaction path for $\mathrm{N}$-alkenylphthalimides with electron-donating olefinic moieties.

Earlier, we reported a further type of photocyclization for $\mathrm{N}$ alk-4-or -5-enylphthalimides; ${ }^{5}$ here we present full details of this work.

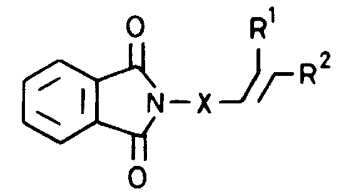

$$
\begin{gathered}
\text { (1a) }-X-=-\left(C_{2}\right)_{3}-, R^{1}=R^{2}=H \\
(1 \mathrm{~b})-X-=-\left(C H_{2}\right)_{4}-, R^{\prime}=R^{2}=H \\
\text { (1c) }-X-=-\left(H_{2} O C H_{2}-, R^{\prime}=R^{2}=H\right. \\
\text { (1d) }-X-=-\left(H_{2} C H_{2} O-, R^{\prime}=R^{2}=H\right. \\
\text { trans }-(1 e),-X-=-\left(C_{2}\right)_{3}-, R^{\prime}=H, R^{2}=M e \\
\text { cis }-(1 e),-X-=-\left(C_{2}\right)_{3}-, R^{\prime}=M e, R^{2}=H
\end{gathered}
$$

\section{Results and Discussion}

Irradiation of the Phthalimide (1a). - An acetonitrile solution of $\mathrm{N}$-pent-4-enylphthalimide (1a) was irradiated under $\mathrm{N}_{2}$ with a high-pressure mercury-lamp. Chromatography of the product gave (2a) in a yield of $92 \%$ based on starting material consumed (Scheme 1). The structure of (2a) was assigned as $1,2,3,10,11,11$ a-hexahydro- $5 H$-pyrrolo[1,2-b][2]benzazepine-<smiles>C=CCCN1C(=O)c2ccccc2C1=O</smiles>

(1a)

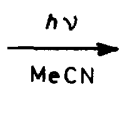<smiles>O=C1CC2CCCN2C(=O)c2ccccc21</smiles>

(2a)

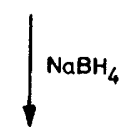<smiles>O=C1c2ccccc2[C@@H](O)CC2CCCN12</smiles>

(3)
Scheme 1.

5,10-dione on the basis of i.r., ${ }^{1} \mathrm{H}$ and ${ }^{13} \mathrm{C}$ n.m.r., and mass spectral evidence, its elemental analysis, and the chemical manipulations outlined below.

The mass spectrum and elemental analysis of (2a) showed that it was an isomer of the starting material (1a); its i.r. spectrum showed absorption at 1675 and $1625 \mathrm{~cm}^{-1}$ characteristic of a ketone carbonyl group (phenyl alkyl ketone type) and amide carbonyl group, respectively. The ${ }^{13} \mathrm{C}$ n.m.r. spectrum of (2a) also showed the presence of two carbonyl groups, i.e. two carbonyl carbons at $\delta 166$ (amide CO) and 201 (ketone $\mathrm{CO}$ ). Further, the ${ }^{13} \mathrm{C}$ n.m.r. spectrum showed four kinds of methylene carbons (triplet signals) at $\delta 23,32$, and 47 $\left(\mathrm{COCH}_{2}\right), 52\left(\mathrm{NCH}_{2}\right)$, and a single methine carbon (doublet signals) at $\delta 53(\mathrm{NCH})$. The ${ }^{1} \mathrm{H}$ n.m.r. spectrum showed the presence of a methylene group adjacent to the ketone carbonyl group and methine carbon $\left(\mathrm{COCH}_{2} \mathrm{CH}\right)$ at $\delta 2.72\left(\mathrm{dd}, J_{1.2} 3\right.$, $J_{\mathrm{AB}} 18 \mathrm{~Hz}$ ) and $2.98\left(\mathrm{dd}, J_{1,2} 12, J_{\mathrm{AB}} 18 \mathrm{~Hz}\right.$ ), and a methine group adjacent to two methylene groups and a nitrogen atom $\left[\mathrm{COCH}_{2} \mathrm{CH}(\mathrm{N}) \mathrm{CH}_{2}\right]$ at $\delta 4.18(\mathrm{~m})$, as could be expected from the assigned structure.

The presence of the ketone carbonyl group in the structure of (2a) was further supported by reduction with sodium 
borohydride in ethanol (Scheme 1). The reduction of (2a) gave an alcohol (3) $(71 \%)$, the i.r. spectrum of which showed a single carbonyl absorption band at $1619 \mathrm{~cm}^{-1}$ (amide) and an absorption band at $3320 \mathrm{~cm}^{-1}(\mathrm{OH})$. The ${ }^{1} \mathrm{H}$ n.m.r. spectrum of (3) showed doublet of doublets signals at $\delta 3.92\left(J_{1,2} 8,10 \mathrm{~Hz}\right)$ due to the methine hydrogen $(H \mathrm{COH})$. The methylene signals observed at $\delta 2.72$ and 2.98 in the ${ }^{1} \mathbf{H}$ n.m.r. spectrum of (2a) shifted to the higher field at $\delta 1.5-2.5$ in that of (3).

Irradiation of (1a) in methanol gave a product identical with (2a) $(70 \%)$.

Irradiation of the Phthalimide (1b).- An acetonitrile solution of $N$-hex-5-enylphthalimide (1b) was irradiated in a similar manner. Chromatography gave (2b) $(32 \%)$ and (4) $(25 \%)$ (Scheme 2).

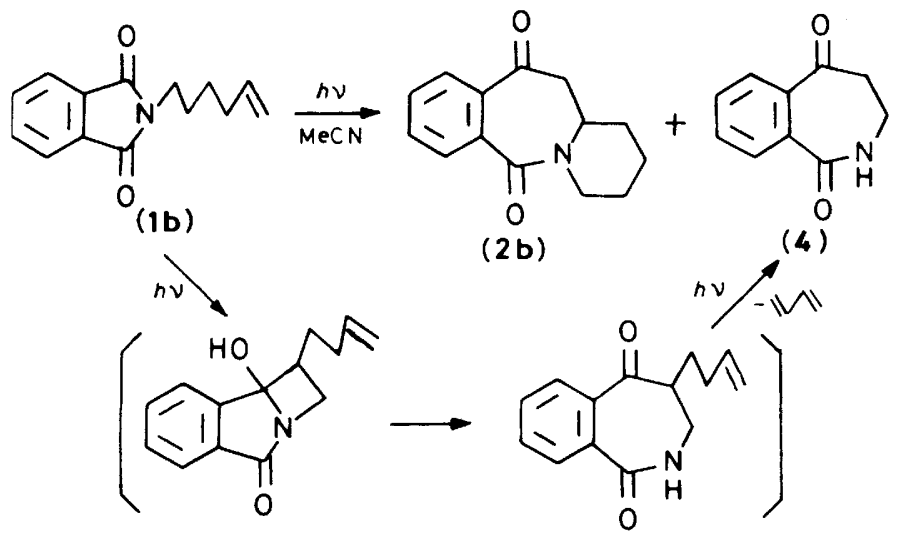

(5)

Scheme 2.

In the ${ }^{1} \mathbf{H}$ n.m.r. spectrum of $(\mathbf{2 b})$, the results of spindecoupling experiments were also in complete accord with the proposed structure and chemical-shift assignments. Irradiation of multiplet signals (NCH) centred at $\delta 4.23$ caused the two doublets of doublets $\left(\mathrm{COCH}_{2}, J_{1,2}, 2, J_{\mathrm{AB}} 19 \mathrm{~Hz}\right.$ and $J_{1,2} 12$, $J_{\mathrm{AB}} 19 \mathrm{~Hz}$ ) centred at $\delta 2.55$ and 3.29 , respectively, to collapse into $\mathrm{AB}$ quartet (two doublets $J_{\mathrm{AB}} 19 \mathrm{~Hz}$ ). Irradiation of complex signals $\left(\mathrm{CH}_{2} \mathrm{CH}_{2} \mathrm{CH}_{2} \mathrm{CH}_{2} \mathrm{~N}\right.$-) centred at $\delta 1.74$ caused both multiplets $\left(\mathrm{CH}_{2} \mathrm{~N}\right)$ centred at $\delta 3.05$ and 4.27 to collapse into an $\mathrm{AB}$ quartet $\left(2 \mathrm{~d} J_{\mathrm{AB}} 12 \mathrm{~Hz}\right)$, and multiplets $(\mathrm{NCH})$ centred at $\delta 4.23$ to collapse into a doublet of doublets $\left(J_{1,2} 2,12\right.$ $\mathrm{Hz}$ ). The anisotropic shielding effect of the phenyl ring and the carbonyl group is probably responsible for a considerable difference of the chemical shifts due to the two pairs of geminal methylene hydrogens $\left(\delta 2.55\right.$ and 3.29 for $\mathrm{COCH}_{2}, \delta 3.05$ and 4.27 for $\mathrm{NCH}_{2}$ ). The other spectral data also support structure of (2b).

The minor product (4) was shown to be identical with the sample obtained by photoreaction of $N$-butylphthalimide. ${ }^{6}$ Formation of (4) may be rationalized on the basis of a two-fold $\gamma$-hydrogen abstraction mechanism (Scheme 2); ${ }^{6}$ i.e. the first $\gamma$ hydrogen abstraction by the imide carbonyl group $(\mathbf{1 b}) \rightarrow(5)$, followed by 1,3 -hydrogen migration $(5) \rightarrow(6)$, and the second $\gamma$ hydrogen abstraction by the ketone carbonyl group $(6) \rightarrow(4)$.

Irradiation of the Phthalimide (1c).-An acetonitrile solution of $\mathrm{N}$-allyloxymethylphthalimide (1c) was irradiated to give (2c) $(15 \%)$ (Scheme 3). Major products in the reaction were $\delta$ hydrogen abstraction-cyclization products (7) $(60 \%)$, a mixture of the two diastereoisomers, probably caused by the presence of an activated $\delta$-methylene group by the neighbouring $-\mathrm{O}-$ and $-\mathrm{CH}=\mathrm{CH}_{2}$ groups.<smiles>C=CC(C)(C)[C@H]1OCN2C(=O)c3ccccc3C12O</smiles>

Scheme 3.

Irradiation of the Pthalimide (1d). - In acetonitrile, irradiation of $N$-(2-vinyloxyethyl)phthalimide (1d) gave (2d) $(62 \%)$ (Scheme 4) However, compared with that of (1a) the cyclization

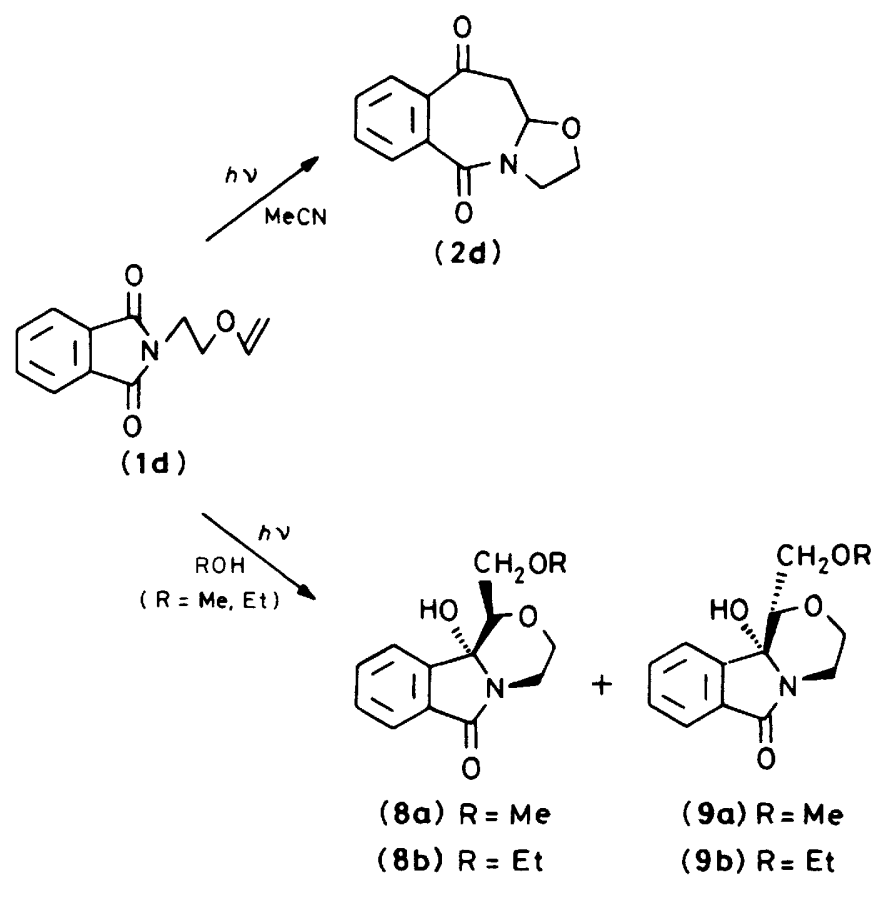

Scheme 4.

of (1d) was considerably slower; the rates for disappearance of (1a) and (1d) in acetonitrile (23 $\mathrm{mm}$ ) were in the ratio of 20:1.

In contrast, irradiation in alcohol gave solvent-incorporated cyclization products. Thus, photolysis of (1d) in methanol gave (8a) $(47 \%)$ and (9a) $(22 \%)$, and in ethanol (8b) $(43 \%)$ and $(9 b)$ $(19 \%)$.

The structure and stereochemistry of these products were assigned on the basis of i.r., ${ }^{1} \mathrm{H}$ n.m.r., and mass spectral evidence, elemental analyses, chemical manipulations, and an $X$-ray diffraction analysis. The i.r. spectra of (8a) and (9a) showed absorption at, respectively, 1674 and $1670 \mathrm{~cm}^{-1}$ (amide $\mathrm{CO}$ ) and 3300 and $3280 \mathrm{~cm}^{-1}(\mathrm{OH})$. The ${ }^{1} \mathrm{H}$ n.m.r. spectra of (8a) and (9a) showed singlets at $\delta 2.92$ and 3.44 (OMe), respectively. The anisotropic shielding effect of the phenyl ring is probably responsible for the different chemical shifts of the two methoxy groups.

The products (8a) and (9a) were found to be very sensitive to acid. On being treated with a drop of hydrochloric acid in chloroform, (8a) and (9a) were dehydrated to give (10a) $(73 \%)$ (Scheme 5$)$. The products $(8 \mathrm{~b})$ and $(9 \mathrm{~b})$ also gave $(10 \mathrm{~b})(93 \%)$ by the same procedure. On the other hand, (10b) was oxidized by chromic acid in acetic acid to (11). The imide (11) was also obtained by an alternative synthesis, i.e. esterification of 


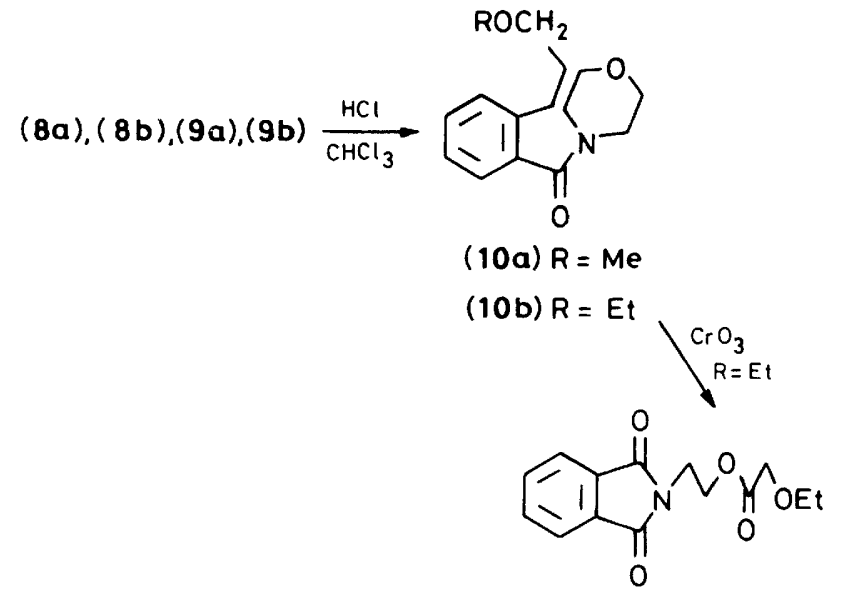

(11)<smiles>CCOCC(=O)O</smiles>

Scheme 5.

ethoxyacetic acid by $N$-(2-hydroxyethyl)phthalimide, using dicyclohexylcarbodi-imide (DCC) in acetonitrile.

Finally, the structure and stereochemistry of (8a) was confirmed by an $X$-ray diffraction analysis. From the stereoscopic view shown in the Figure, the structure of (8a) is seen to possess an endo-methoxymethyl group.

Irradiation of the Phthalimides cis-(1e) and trans-(1e).Photolysis of cis-(1e) and trans-(1e) (cis- and trans- $N$-hex-4enylphthalimide) was examined in order to clarify the stereochemical course of the photocyclization. The imides were prepared by the reaction of potassium phthalimide and the corresponding chlorides.

In acetonitrile, irradiation of $c i s$-(1e) for 8 days gave a mixture of two cyclization products which were separated by h.p.l.c. The structures of the products were readily assigned by comparison of their ${ }^{1} \mathrm{H}$ n.m.r. spectra with those of the analogous products (2a-d); stereochemical assignments were made on the basis of the results reported by Mazzocchi and his co-workers. ${ }^{7}$ The cyclization product with the $2 \mathrm{~Hz}$ coupling between $\mathrm{H}_{\mathrm{a}}$ and $\mathrm{H}_{\mathrm{b}}$ (Scheme 6) was assigned to the cis-isomer cis-(2e) and with the

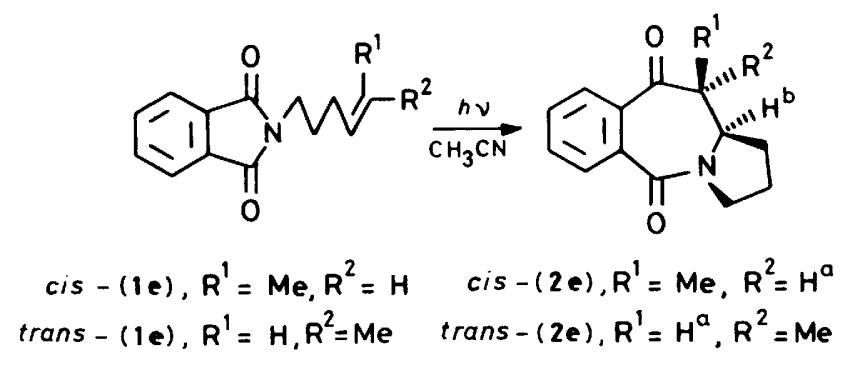

Scheme 6.

$12 \mathrm{~Hz}$ coupling to the trans-isomer trans-(2e). The isomer ratio of $\operatorname{cis}$-(2e):trans-(2e) in the reaction was $2: 3$ after irradiation for 8 days.
Time dependent yields of the two products in the photolysis of $c i s-(1 \mathbf{e})$ or trans-(1e) were examined by means of h.p.l.c. The results clearly indicated that the photocyclization was stereospecific; irradiation of cis-(1e) gave cis-(2e) selectively [cis(2e): trans-(2e) $=95: 3]$ and that of trans-(1e) gave trans-(2e) selectively $[$ trans $-(2 \mathrm{e}):$ cis $-(\mathbf{2 e})=63: 13]$ at the low conversion.

Cyclization accompanying Imide $\mathrm{C}(=\mathrm{O})-\mathrm{N}$ Bond Cleavage.The intermolecular addition reaction to give benzazepinediones observed in the photolysis of $\mathrm{N}$-methylphthalimide and olefins also occurred with isobutene and styrene (Scheme 7). ${ }^{5}$<smiles>CN1C(=O)c2ccccc2C1=O</smiles><smiles>[R]C([CH])=CC</smiles><smiles>[R]C1([R])CN(C)C(=O)c2ccccc2C1=O</smiles>

\section{$R^{1}=R^{2}=$ Me or} $R^{1}=R^{2}=$ Me or $R^{1}=P h, R^{2}=H$ $R^{1}=P h, R^{2}=H$

Scheme 7.
Independently, similar intermolecular addition reactions have been found by other groups: thus, $N$-methylphthalimide has been reported to react with dienes, ${ }^{8}$ alkenes, ${ }^{9}$ vinyl ethers, ${ }^{10}$ vinyl esters, ${ }^{11}$ and allenes. ${ }^{11}$ In addition, Mazzocchi and his coworkers have reported that the addition reaction with cis- and trans-but-2-ene was stereospecific, ${ }^{7}$ and that of 4-methoxy- $N$ methylphthalimide with olefins was regioselective. ${ }^{12}$

For the intramolecular photoreaction, it is interesting to consider how the position of the double bond affects the reaction. Thus, in the photolysis of simple carbonyl compounds the most favourable double bond for intramolecular oxetane is in the $\gamma, \delta$-position $;^{13}$ this corresponds to unsaturation at the 2position in $\mathrm{N}$-alkenylimide systems. Thus, photolysis of $\mathrm{N}$ allylsuccinimide in methanol gave mainly oxetanes via intramolecular cyclization, ${ }^{2 a}$ whereas irradiation of $N$-but-3enyl- and $N$-pent-4-enyl-succinimide in methanol afforded mainly $\gamma$-hydrogen abstraction products. Preference of the $\mathrm{N}$ alk-2-enyl double bond for oxetane formation was explained in terms of attack of the $n \pi^{*}$ excited carbonyl oxygen onto the double bond via a six-membered transition state.

In the intramolecular cyclizations of $(\mathbf{1 a -}-\mathbf{e})$ to give $(2 \mathbf{a}-\mathbf{e})$ which accompanied imide $\mathrm{C}(=\mathrm{O})-\mathrm{N}$ bond cleavage, the former reactions occurred for only a limited number of the $N$ alkenylphthalimides; the $N$-alk-4-enyl double bond, which corresponds to the $\varepsilon, \zeta$-position was highly favoured for the reaction. Photolysis of $N$-(alk-2-enyl)phthalimides in acetonitrile gave none of the cyclization product. ${ }^{3 a}$ Photoreaction of $\mathrm{N}$-but-3-enylphthalimide in acetonitrile to give (12) $(27 \%)$ was slow compared with that of (1a).<smiles>O=C1c2ccccc2C2(O)C=CCCN12</smiles>

(12)

In compounds of the type $A-\left(\mathrm{CH}_{2}\right)_{n}-\mathrm{D}$, in which $\mathrm{A}$ and $\mathrm{D}$ are different $\pi$-systems, the efficiency of the intramolecular reaction is known to be a function of $n$. Often, for $n=3$, an optimal 

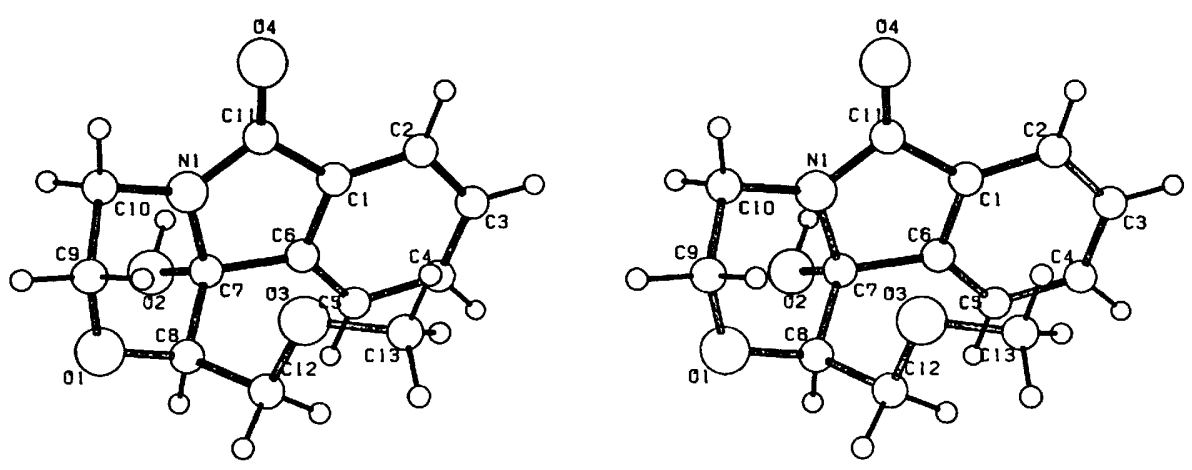

Figure. Stereoscopic view of (8a).

situation is attained as a result of steric factors. ${ }^{14}$ In our study, $N$-pent-4-enylphthalimide (1a) corresponds to an A- $\left(\mathrm{CH}_{2}\right)_{3}-\mathrm{D}$ system, in which $\mathrm{D}$ is $-\mathrm{CH}=\mathrm{CH}_{2}$ and $\mathrm{A}$ is $\mathrm{CO} \cdot \mathrm{C}_{6} \mathrm{H}_{4} \mathrm{CO} \cdot \mathrm{N}-$. Thus, (1a) may most efficiently form the intramolecular cyclization product (2a). The regiochemistry of the intermolecular addition reaction (Scheme 7) is different from that of the intramolecular reaction. The observed regiochemistry of the cyclization may indicate that steric factors play a more important role than electronic factors in the intramolecular reaction. Stereospecificity of the reaction may provide evidence that the cyclization arises directly from the singlet excited state of $N$-alkenylphthalimides.

Two Different Types of Cyclization Reaction of the Phthalimide (1d).- In acetonitrile, the efficiency of the cyclization reactions of (1d) with the vinyl ether moiety was much lower than that of (1a) with the simple ethylene moiety. This result can be interpreted in terms of apparent difficulties of electron transfer from the double bond to the excited imide (Scheme 8). Initial electron transfer may regenerate the starting

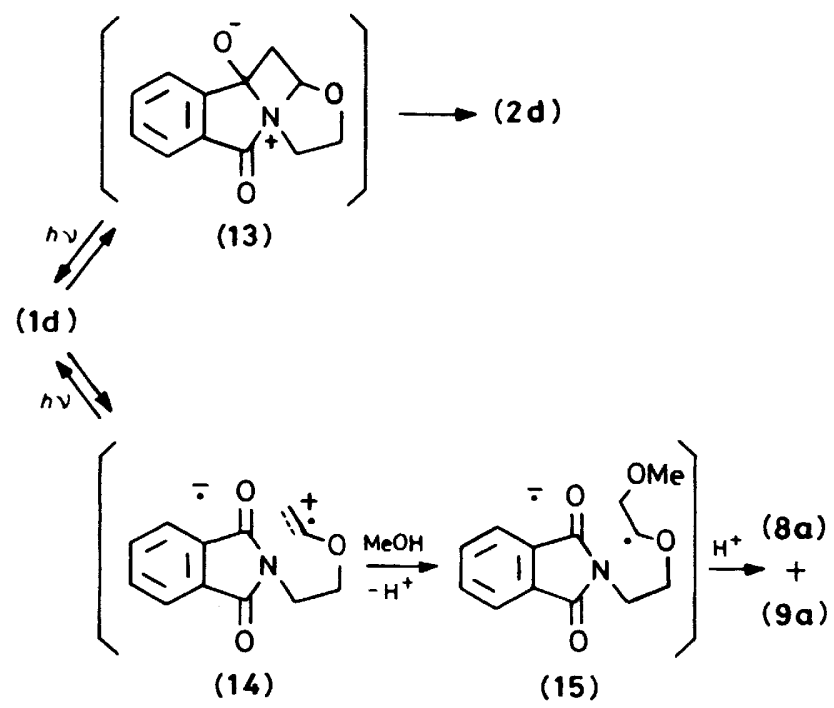

Scheme 8.

material via back electron transfer, which competes with the cyclization in cases where the ionization potential of the double bond is low enough. Thus, in methanol (14) can be trapped to give different types of cyclization product; the methanolincorporated cyclization products (8a) and (9a). The structural and stereochemical features of (8a) and (9a) are nicely rationalized on the basis of an electron transfer mechanism (Scheme 5); here radical (15) is involved which is more stable than that formed by addition of methanol to the non-terminal alkene carbon.

\section{Experimental}

M.p.s were measured on a Yanagimoto micromelting point apparatus and are uncorrected. ${ }^{1}$ H N.m.r. spectra were recorded on a JEOL PS-100 spectrometer $(100 \mathrm{MHz})$. Chemical shifts are reported in p.p.m. $(\delta)$ relative to internal $\mathrm{SiMe}_{4}$. I.r. spectra were obtained with a JASCO IR-G spectrophotometer calibrated against the $1601 \mathrm{~cm}^{-1}$ peak of polystyrene. Mass spectra were taken with a Hitachi M-52 mass spectrometer. Microanalyses were carried out by the Microanalytical Laboratory of Kyoto University, Kyoto, Japan.

Preparation of Alkenylphthalimides (1a-e).-N-Pent-4enylphthalimide (1a), m.p. $40-41^{\circ} \mathrm{C}$ (lit., ${ }^{15} 34-35^{\circ} \mathrm{C}$ ), was prepared by the method of Kirmse and Grassmann. ${ }^{15}$ Analogously, $N$-hex-5-enylphthalimide (1b) was prepared by the reaction of 1-chlorohex-5-ene ${ }^{16}$ and potassium phthalimide in $65 \%$ yield (based on 1-chlorohex-5-ene): b.p. $165-167{ }^{\circ} \mathrm{C} / 2$ Torr; $\delta_{\mathrm{H}}\left(\mathrm{CDCl}_{3}\right) 1.3-1.9(4 \mathrm{H}, \mathrm{m}), 2.12\left(2 \mathrm{H}, \mathrm{q}, J_{1,2} 7 \mathrm{~Hz}\right), 3.67$ $\left(2 \mathrm{H}, \mathrm{t}, J_{1,2} 7 \mathrm{~Hz}\right), 4.8-5.1(2 \mathrm{H}, \mathrm{m})$, and $5.5-6.1(1 \mathrm{H}, \mathrm{m}), 7.6$ $8.0(4 \mathrm{H}, \mathrm{m}) ; v_{\max }$. (neat) 1765,1712 (imide), $1390,1365,1038$, 913 , and $715 \mathrm{~cm}^{-\mathrm{i}} ; m / z(20 \mathrm{eV}) 229\left(29, M^{+}\right), 161(80), 160(100)$, 148 (88), and 82 (51) (Found: $\mathrm{C}, 73.1 ; \mathrm{H}, 6.6 ; \mathrm{N}, 6.1 . \mathrm{C}_{14} \mathrm{H}_{15} \mathrm{NO}_{2}$ requires $\mathrm{C}, 73.3 ; \mathrm{H}, 6.6 ; \mathrm{N}, 6.1 \%$ ).

$N$-Allyloxymethylphthalimide (1c) was prepared as follows. $\mathrm{N}$-Bromomethylphthalimide (12 $\mathrm{g})$ was added to a solution of sodium $(1.2 \mathrm{~g})$ in allyl alcohol $(50 \mathrm{ml})$ with stirring ${ }^{17}$ and the stirring continued for $1 \mathrm{~h}$ at room temperature; the solution was subsequently refluxed for $1 \mathrm{~h}$. The excess of allyl alcohol was removed under reduced pressure and the residue extracted with chloroform $(20 \mathrm{ml})$. The extract was washed with water $(10 \mathrm{ml})$ and dried $\left(\mathrm{Na}_{2} \mathrm{SO}_{4}\right)$. Distillation of the solution gave (1c) (7.6 g), b.p. $141-144{ }^{\circ} \mathrm{C} / 2$ Torr, which crystallized with time; m.p. $45-47^{\circ} \mathrm{C} ; \delta_{\mathrm{H}}\left(\mathrm{CDCl}_{3}\right) 4.11\left(2 \mathrm{H}, \mathrm{d}, J_{1.2} 6 \mathrm{~Hz}\right), 5.16(2 \mathrm{H}, \mathrm{s})$, $5.0-5.5(2 \mathrm{H}, \mathrm{m}), 5.6-6.1(1 \mathrm{H}, \mathrm{m})$, and $7.6-8.0(4 \mathrm{H}, \mathrm{m})$; $v_{\text {max. }}(\mathrm{KBr}) 1$ 771, 1720 (imide), 1355,1 330, 1 200, 1070,725 , and $705 \mathrm{~cm}^{-1} ; m / z(20 \mathrm{eV}) 217\left(1, M^{+}\right), 162(13), 161(88)$, and 160 (100) (Found: $\mathrm{C}, 66.1 ; \mathrm{H}, 5.4 ; \mathrm{N}, 6.5 . \mathrm{C}_{12} \mathrm{H}_{11} \mathrm{NO}_{3}$ requires C, 66.4; H, 5.1; N, 6.5\%).

Analogously to (1a), $N$-(2-vinyloxyethyl)phthalimide (1d) was prepared by the reaction of 2-chloroethyl vinyl ether and potassium phthalimide in $58 \%$ yield (based on 2-chloroethyl vinyl ether): m.p. $115-115.5^{\circ} \mathrm{C}$ (from ethanol); $\delta_{\mathrm{H}}\left(\mathrm{CDCl}_{3}\right.$ ) $3.8-4.4(6 \mathrm{H}, \mathrm{m}), 6.42\left(1 \mathrm{H}, \mathrm{dd}, J_{1,2} 7 \mathrm{~Hz}, J_{\mathrm{AB}} 14 \mathrm{~Hz}\right)$, and $7.6-$ $8.0(4 \mathrm{H}, \mathrm{m}) ; v_{\text {max. }}(\mathrm{KBr}) 1$ 765, 1712 (imide), $1613,1419,1385$, 
$1317,1190,996$, and $825 \mathrm{~cm}^{-1} ; m / z(20 \mathrm{eV}) 217\left(3, M^{+}\right), 175$ (12), $174(100), 171(17), 161$ (6), $160(34), 147$ (12), and 130 (17) (Found: $\mathrm{C}, 66.5 ; \mathrm{H}, 5.4 ; \mathrm{N}, 6.5 . \mathrm{C}_{12} \mathrm{H}_{11} \mathrm{NO}_{3}$ requires $\mathrm{C}, 66.4 ; \mathrm{H}$, $5.1 ; \mathrm{N}, 6.5 \%$ ).

trans- $N$-Hex-4-enylphthalimide trans-(1e) was prepared by the reaction of trans-1-chlorohex-4-ene ${ }^{18}$ and potassium phthalimide in $65 \%$ yield (based on trans-1-chlorohex-4-ene): m.p. $55.0-57.0^{\circ} \mathrm{C}$, b.p. $105^{\circ} \mathrm{C} / 1$ Torr; $\delta_{\mathrm{H}}\left(\mathrm{CDCl}_{3}\right) 1.59(3 \mathrm{H}$, d, $\left.J_{1.2} 4 \mathrm{~Hz}\right), 1.6-2.2(4 \mathrm{H}, \mathrm{m}), 3.56\left(2 \mathrm{H}, \mathrm{t}, J_{1.2} 8 \mathrm{~Hz}\right), 5.32(2 \mathrm{H}$, $\mathrm{m})$, and $7.5-7.8(4 \mathrm{H}, \mathrm{m}) ; v_{\max }(\mathrm{KBr}) 1715$ (imide) and 960 $\mathrm{cm}^{-1} ; m / z(20 \mathrm{eV}) 229\left(60, M^{+}\right), 161(100)$, and $160(100)$ (Found: $\mathrm{C}, 73.5 ; \mathrm{H}, 6.5 ; \mathrm{N}, 6.1 . \mathrm{C}_{14} \mathrm{H}_{15} \mathrm{NO}_{2}$ requires $\mathrm{C}, 73.3 ; \mathrm{H}$, $6.6 ; \mathrm{N}, 6.1 \%$ ).

cis- $N$-Hex-4-enylphthalimide cis-(1e) was prepared by the reaction of cis-1-chlorohex-4-ene and potassium phthalimide. cis-1-Chlorohex-4-ene was prepared as follows. n-Butyl-lithium $(0.15 \mathrm{~mol})$ and then methyl iodide $(0.15 \mathrm{~mol})$ were added to a solution of 1-chloropent-4-yne in dry ether. The mixture was stirred overnight at room temperature after which it was quenched with saturated aqueous sodium chloride and extracted with ether $(5 \times 50 \mathrm{ml})$. Distillation of the extract gave 1-chlorohex-4-yne. To 1-chlorohex-4-yne (1 g) was a $1 \mathrm{M}$ $\mathrm{BH}_{3}$. THF solution $(5 \mathrm{ml})$ and trimethylethylene $(2.12 \mathrm{ml})$. The mixture was stirred for $2 \mathrm{~h}$ after which acetic acid $(1 \mathrm{ml})$ was added; the mixture was then stirred overnight. The solution was extracted with ether and the extract was washed with saturated aqueous sodium hydrogen carbonate and dried $\left(\mathrm{MgSO}_{4}\right)$. The solvent, was evaporated and the residue chromatographed over basic alumina with light petroleum as eluant to give cis-1chlorohex-4-ene in $42 \%$ yield (based on 1-chloropent-4-yne): b.p. $105^{\circ} \mathrm{C} / 1$ Torr; $\delta_{\mathrm{H}}\left(\mathrm{CDCl}_{3}\right) 1.59\left(3 \mathrm{H}, \mathrm{d}, J_{1,2} 4 \mathrm{~Hz}\right), 1.6-2.2$ $(4 \mathrm{H}, \mathrm{m}), 3.64\left(2 \mathrm{H}, \mathrm{t}, J_{1,2} 7 \mathrm{~Hz}\right), 5.34(2 \mathrm{H}, \mathrm{m})$, and $7.5-7.9(4 \mathrm{H}$, $\mathrm{m})$; $v_{\text {max. }}$ (neat) 1715 (imide) $\mathrm{cm}^{-1} ; m / z(20 \mathrm{eV}) 229\left(60, M^{+}\right), 161$ $(100)$, and $160(100)$.

Irradiation of Compound (1a).-A solution of (1a) $(3.00 \mathrm{~g}$, $0.014 \mathrm{~mol}$ ) in acetonitrile $(400 \mathrm{ml})$ was placed in a photolysis cell equipped with a gas inlet tube, reflux condenser, and a watercooled immersion well. The solution was deoxygenated by passing a stream of nitrogen through it for $30 \mathrm{~min}$, the flow being decreased. The solution was irradiated with a $300-\mathrm{W}$ high-pressure Eikosha $\mathrm{Hg}$-arc lamp. After 12 h t.l.c. (Merk Silica gel $\mathrm{HF}_{254}$-Type 60) analysis with ether as developer showed that the starting material had nearly disappeared and a product $(2 \mathrm{~g}), R_{\mathrm{F}} 0.4$, was present. This was isolated by column chromatography over silica gel $(20 \mathrm{~g} ; 2 \mathrm{~cm} \times 10 \mathrm{~cm})($ Wakogel C-200) with ether as eluant; yield of $2.73 \mathrm{~g}(91 \%)$. Recrystallization of the product from ethyl acetate-hexane gave white crystals of $1,2,3,10,11,11 \mathrm{a}$-hexahydro- $5 \mathrm{H}$-pyrrolo[1,2-b][2]benzazepine-5,10-dione (2a), m.p. $129.5-130.5^{\circ} \mathrm{C} ; \delta_{\mathrm{H}}\left(\mathrm{CCl}_{4}\right)$ $1.6-2.5(4 \mathrm{H}, \mathrm{m}), 2.72\left(1 \mathrm{H}, \mathrm{dd}, J_{1,2} 3 \mathrm{~Hz}, J_{\mathrm{AB}} 18 \mathrm{~Hz}\right), 2.98(1 \mathrm{H}$, dd, $\left.J_{1,2} 12 \mathrm{~Hz}, J_{\mathrm{AB}} 18 \mathrm{~Hz}, \mathrm{COCH}_{2}\right), 3.6-3.8\left(2 \mathrm{H}, \mathrm{m}, \mathrm{NCH}_{2}\right)$, $4.18(1 \mathrm{H}, \mathrm{m}, \mathrm{NCH})$, and 7.4-8.0 (4 H, m, $\mathrm{ArH}) ; \delta_{\mathrm{c}}\left(\mathrm{CDCl}_{3}\right) 23$ (t), 32 (t), 47 (t), 51 (t), 53 (d), 128, 130, 131, 132, 134, 136 (arom C), 166 (amide), and 201 (ketone); $v_{\max .}(\mathrm{KBr}) 1675$ (ketone), 1625 (amide), 1448,1422 , and $1280 \mathrm{~cm}^{-1} ; m / z(20 \mathrm{eV}) 215(95$, $M^{+}$), and $146(100)$ (Found: $\mathrm{C}, 72.3 ; \mathrm{H}, 6.0 ; \mathrm{N}, 6.6 . \mathrm{C}_{13} \mathrm{H}_{13} \mathrm{NO}_{2}$ requires $\mathrm{C}, 72.5 ; \mathrm{H}, 6.1 ; \mathrm{N}, 6.5 \%$ ).

Reduction of (2a) with Sodium Borohydride.-Sodium borohydride ( $5 \mathrm{mg}$ ) was added to a solution of $(2 \mathrm{a})(200 \mathrm{mg})$ in ethanol $(20 \mathrm{ml})$ and the solution was left overnight at room temperature. The solution was poured into $0.1 \mathrm{M}$-hydrochloric acid $(50 \mathrm{ml})$ and extracted with chloroform $(2 \times 20 \mathrm{ml})$. The combined extracts were washed with water $(20 \mathrm{ml})$ and dried $\left(\mathrm{MgSO}_{4}\right)$. After evaporation, chromatography over silica gel with dichloromethane as eluant gave $1,2,3,10,11,11 \mathrm{a}$-hexahydro-10-hydroxy-5H-pyrrolo[1,2-b][2]benzazepine-5-one (3)
(143 mg, 71\%); a minor product, presumably a stereoisomer of (3), was detectable but not isolated: (3), m.p. $151-153^{\circ} \mathrm{C}$ (from ethanol); $\delta_{\mathrm{H}}\left(\mathrm{CDCl}_{3}\right) 1.5-2.5(6 \mathrm{H}, \mathrm{m}), 3.2-3.7(3 \mathrm{H}, \mathrm{m}), 3.92(1$ $\left.\mathrm{H}, \mathrm{dd}, J_{1,2} 8,10 \mathrm{~Hz}, H \mathrm{COH}\right), 4.48(1 \mathrm{H}, \mathrm{s}, \mathrm{OH})$, and 7.2-7.8 (4 $\mathrm{H}, \mathrm{m}, \mathrm{ArH}) ; v_{\max }(\mathrm{KBr}) 3320(\mathrm{OH}), 1619$ (amide), 1 595, 1432 , and $1068 \mathrm{~cm}^{-1} ; m / z(20 \mathrm{eV}) 217\left(51, M^{+}\right), 199(34), 83(15), 70$ (100), and 49 (25) (Found: $\mathrm{C}, 71.7 ; \mathrm{H}, 6.9 ; \mathrm{N}, 6.2 . \mathrm{C}_{13} \mathrm{H}_{15} \mathrm{NO}_{2}$ requires $\mathrm{C}, 71.9 ; \mathrm{H}, 7.0 ; \mathrm{N}, 6.5 \%$ ).

Irradiation of Compound (1 b). - A solution of $(1 \mathbf{b})(300 \mathrm{mg})$ in acetonitrile $(20 \mathrm{ml})$ was irradiated for $c a .2$ days. Column chromatography of the product over silica gel with ether as eluant gave (2b) and (4) in yields of $38 \mathrm{mg} \mathrm{(32 \% )} \mathrm{and} 23 \mathrm{mg}$ $(25 \%)$, respectively.

1,2,3,4,6,11,12,12a-Octahydropyrido[1,2-b][2]benzazepine6,11-dione (2b), m.p. $126-128^{\circ} \mathrm{C}$ (from hexane); $\delta_{\mathrm{H}}\left(\mathrm{CDCl}_{3}\right)$ $1.4-2.1(6 \mathrm{H}, \mathrm{m}), 2.55\left(1 \mathrm{H}, \mathrm{dd}, J_{1,2} 2 \mathrm{~Hz}, J_{\mathrm{AB}} 19 \mathrm{~Hz}, \mathrm{COCH}_{2}\right)$, $3.05\left(1 \mathrm{H}, \mathrm{m}, \mathrm{NCH}_{2}\right), 3.29\left(1 \mathrm{H}, \mathrm{dd}, J_{1,2} 12 \mathrm{~Hz}, J_{\mathrm{AB}} 19 \mathrm{~Hz}\right.$, $\left.\mathrm{COCH}_{2}\right), 4.23(1 \mathrm{H}, \mathrm{m}, \mathrm{NCH}), 4.27\left(1 \mathrm{H}, \mathrm{m}, \mathrm{NCH}_{2}\right)$, and 7.48.0 (4 H, m, ArH); $v_{\max .}(\mathrm{KBr}) 2950$ and 1680 (ketone), 1626 (amide), $1596,1414,1276,1252,796,763$, and $711 \mathrm{~cm}^{-1} ; \mathrm{m} / z$ (20 eV) $229\left(55, M^{+}\right), 146(20), 83(100)$, and 43 (35) (Found: C, 73.2; $\mathrm{H}, 6.6 ; \mathrm{N}, 6.3 . \mathrm{C}_{14} \mathrm{H}_{15} \mathrm{NO}_{2}$ requires $\mathrm{C}, 73.3 ; \mathrm{H}, 6.6 ; \mathrm{N}$, $6.1 \%$ ).

6,7-Dihydro-3,4-benzazepine-2,5-dione (4), m.p. $165.0-166^{\circ} \mathrm{C}$ (from ethyl acetate); $\delta_{\mathrm{H}}\left(\mathrm{CDCl}_{3}\right) 2.98\left(2 \mathrm{H}, \mathrm{t}, J_{1,2} 5 \mathrm{~Hz}, \mathrm{COCH}_{2}\right)$, $3.56(2 \mathrm{H}, \mathrm{q}$, these signals changed to a triplet by shaking with $\left.\mathrm{D}_{2} \mathrm{O}, \mathrm{NHCH}_{2}\right), 7.5-8.2(4 \mathrm{H}, \mathrm{m}, \mathrm{ArH})$, and $8.10(1 \mathrm{H}$, br s, this signal disappeared by shaking with $\left.\mathrm{D}_{2} \mathrm{O}, \mathrm{NH}\right) ; \mathrm{v}_{\max }(\mathrm{KBr}) 3160$ (NH), 1673 (ketone), 1653 (amide), 1 593, 1 408, 1 358, 900, and $760 \mathrm{~cm}^{-1} ; m / z(20 \mathrm{eV}) 175\left(85, M^{+}\right), 104(100)$, and $76(60)$ (Found: $\mathrm{C}, 68.6 ; \mathrm{H}, 5.3 ; \mathrm{N}, 8.1 . \mathrm{C}_{10} \mathrm{H}_{9} \mathrm{NO}_{2}$ requires $\mathrm{C}, 68.6 ; \mathrm{H}$, $5.2 ; \mathrm{N}, 8.0 \%$ ).

Irradiation of Compound (1c).-A solution of (1c) $(300 \mathrm{mg})$ in acetonitrile $(20 \mathrm{ml})$ was irradiated for $c a .2$ days. Column chromatography over silica gel with ether as eluant gave (2c) (35 $\mathrm{mg}, 15 \%)$, (7) (140 mg, 60\%), and starting material (68 mg).

1,10,11,11a-Tetrahydro-5H-2-benzazepino[2,3-c][1,3]oxazole-5,10-dione (2c), m.p. $124-125.5^{\circ} \mathrm{C}$ (from hexane); $\delta_{\mathrm{H}}\left(\mathrm{CDCl}_{3}\right) 2.98\left(1 \mathrm{H}, \mathrm{dd}, J_{1,2} 2 \mathrm{~Hz}, J_{\mathrm{AB}} 19 \mathrm{~Hz}, \mathrm{COCH}_{2}\right), 3.26(1$ $\left.\mathrm{H}, \mathrm{dd}, J_{1,2} 10 \mathrm{~Hz}, J_{\mathrm{AB}} 19 \mathrm{~Hz}, \mathrm{COCH}_{2}\right), 3.9-4.1(1 \mathrm{H}, \mathrm{m}), 4.2-$ $4.5(2 \mathrm{H}, \mathrm{m}), 5.29$ and $5.38\left(2 \mathrm{H}, \mathrm{ABq}, J_{\mathrm{AB}} 10 \mathrm{~Hz}, \mathrm{NCH}_{2} \mathrm{O}\right)$, and 7.4-8.1 (4 H, m, ArH); $v_{\max }(\mathrm{KBr}) 2860,1669$ (ketone), 1624 (amide), $1594,1430,1280,950,759$, and $692 \mathrm{~cm}^{-1} ; m / z(20 \mathrm{eV})$ $217\left(26, M^{+}\right), 162(12), 161(100), 160(26)$, and $146(40)$ (Found: $\mathrm{C}, 66.4 ; \mathrm{H}, 5.0 ; \mathrm{N}, 6.4 . \mathrm{C}_{12} \mathrm{H}_{11} \mathrm{NO}_{3}$ requires $\mathrm{C}, 66.4 ; \mathrm{H}, 5.1 ; \mathrm{N}$, $6.5 \%$ ).

1,9b-Dihydro-9b-hydroxy-1-vinyl-5H-isoindolo[2,1-c][1,3]oxazol-5-one (7) was further purified by recrystallization from the mixture of diastereoisomers: the main diastereoisomer had m.p. $154-156.5^{\circ} \mathrm{C}$ (from ethanol); $\delta_{\mathrm{H}}\left(\mathrm{CDCl}_{3}\right) 3.60(1 \mathrm{H}$, s, $\mathrm{OH}), 4.6-4.8(2 \mathrm{H}, \mathrm{m}), 5.0-5.5(4 \mathrm{H}, \mathrm{m})$, and $7.4-7.8(4 \mathrm{H}, \mathrm{m}$, ArH); $v_{\max }$. $(\mathrm{KBr}) 3320$ (HO), 1676 (amide), 1358,1 269, 1084 , $1078,952,772$, and $724 \mathrm{~cm}^{-1} ; m / z(20 \mathrm{eV}) 162(100), 161(100)$, 160 (18), 133 (15), and 117 (15) (Found: C, 66.2; H, 5.1; N, 6.5. $\mathrm{C}_{12} \mathrm{H}_{11} \mathrm{NO}_{3}$ requires $\mathrm{C}, 66.4 ; \mathrm{H}, 5.1 ; \mathrm{N}, 6.5 \%$ ).

Irradiation of Compound (1d) in Acetonitrile.-A solution of (1d) $(300 \mathrm{mg})$ in acetonitrile $(20 \mathrm{ml})$ was irradiated for $c a$. 2 days. Column chromatography over silica gel with ether as eluant gave 2,3,5,10,11a-hexahydro-2-benzazepino [3,2-b][1,3]oxazole5,10 -dione (2d) $[18 \mathrm{mg}, 60 \%$ based on consumed (1d)]; and starting material $\left(270 \mathrm{mg}\right.$ ) (2d), m.p. $100.0-100.5^{\circ} \mathrm{C}$ (from hexane); $\delta_{\mathrm{H}}\left(\mathrm{CDCl}_{3}\right) 3.07\left(1 \mathrm{H}\right.$, dd, $J_{1,2} 8 \mathrm{~Hz}, J_{\mathrm{AB}} 20 \mathrm{~Hz}$, $\left.\mathrm{COCH}_{2}\right), 3.22\left(1 \mathrm{H}, \mathrm{dd}, J_{1,2} 6 \mathrm{~Hz}, J_{\mathrm{AB}} 20 \mathrm{~Hz}, \mathrm{COCH}_{2}\right), 3.6-4.4$ $(4 \mathrm{H}, \mathrm{m}), 5.51\left(1 \mathrm{H}, \mathrm{dd}, J_{1.2} 6,8 \mathrm{~Hz}, \mathrm{NCHO}\right)$, and $7.4-8.1(4 \mathrm{H}$, $\mathrm{m}, \mathrm{ArH}$ ); $v_{\max }(\mathrm{KBr}) 2890,1684$ (ketone), 1630 (amide), 1 592, 
$1452,1433,1282,972,798,769$, and $709 \mathrm{~cm}^{-1} ; m / z(20 \mathrm{eV}) 217$ $\left(23, M^{+}\right), 147(13), 146(100), 118(13)$, and 104 (13) (Found: C, $66.5 ; \mathrm{H}, 4.9 ; \mathrm{N}, 6.4 . \mathrm{C}_{12} \mathrm{H}_{11} \mathrm{NO}_{3}$ requires $\mathrm{C}, 66.4 ; \mathrm{H}, 5.1 ; \mathrm{N}$, $6.5 \%$ ).

Irradiation of Compound (1d) in Methanol--A solution of (1d) $(500 \mathrm{mg}, 2.3 \mathrm{mmol})$ in methanol $(400 \mathrm{ml})$ was irradiated for ca. $5 \mathrm{~h}$. T.l.c. analysis with ether as developer showed that almost all the starting material had disappeared and products ( $R_{\mathrm{F}} c a .0 .3$ as a broad spot) were present. The latter were separated by column chromatography over silica gel with ether eluant and purified by repeated recrystallization from ethanolether to give the following.

$10 \mathrm{~b} \beta$-Hydroxy-1 1 -methoxymethyl-1,3,4,10b-tetrahydro- $6 \mathrm{H}-$ isoindolo $[1,2-\mathrm{c}][1,4]$ oxazin-6-one (8a) $(47 \%)$, m.p. $131-133{ }^{\circ} \mathrm{C}$; $\delta_{\mathrm{H}} 2.90\left(1 \mathrm{H}, \mathrm{dd}, J_{1,2} 5 \mathrm{~Hz}, J_{\mathrm{AB}} 12 \mathrm{~Hz}\right.$, these signals changed to d, $J_{\mathrm{AB}} 12 \mathrm{~Hz}$ on irradiation at $\left.\delta 4.41, \mathrm{MeOCH}_{2}\right), 2.92(3 \mathrm{H}, \mathrm{s}$, $\left.\mathrm{OCH}_{3}\right), 3.16\left(1 \mathrm{H}, \mathrm{dd}, J_{1.2} 8 \mathrm{~Hz}, J_{\mathrm{AB}} 12 \mathrm{~Hz}\right.$, these signals changed to d, $J_{\mathrm{AB}} 12 \mathrm{~Hz}$ on irradiation at $\delta 4.41, \mathrm{MeOCH}_{2}$ ), $3.14 .1\left(4 \mathrm{H}, \mathrm{m}, \mathrm{NCH}_{2} \mathrm{CH}_{2} \mathrm{O}\right), 4.41\left(1 \mathrm{H}\right.$, dd, $J_{1.2} 5,8 \mathrm{~Hz}$, $\left.\mathrm{OCHCH}_{2}\right), 4.50(1 \mathrm{H}, \mathrm{s}, \mathrm{OH})$, and $7.4-7.7(4 \mathrm{H}, \mathrm{m}, \mathrm{ArH})$; $v_{\text {max. }}(\mathrm{KBr}) 3300(\mathrm{OH}), 2$ 960, 1674 (amide), 1 426, 1 284, 1078 , 1011,782 , and $763 \mathrm{~cm}^{-1} ; m / z(20 \mathrm{eV}) 231$ (22), $217(11), 200(22)$, 175 (19), $174(100), 173(22)$, and 160 (19) (Found: C, 62.9; H, 6.1; $\mathrm{N}, 5.6 . \mathrm{C}_{13} \mathrm{H}_{15} \mathrm{NO}_{4}$ requires $\mathrm{C}, 62.6 ; \mathrm{H}, 6.1 ; \mathrm{N}, 5.6 \%$ ). The precise description on the $X$-ray diffraction analysis of (8a) will be presented by Keiichi Fukuyama (Tottori University) in the near future.

$10 \mathrm{~b} \beta$-Hydroxy-1 $\beta$-methoxymethyl-1,3,4,10b-tetrahydro- $6 \mathrm{H}$ isoindolo $[1,2-\mathrm{c}][1,4]$ oxazin-6-one $(9 \mathrm{a})\left(22^{\circ} \%\right)$, m.p. $190-192{ }^{\circ} \mathrm{C}$; $\delta_{\mathrm{H}}\left(\mathrm{CDCl}_{3}\right) 3.1-3.6(4 \mathrm{H}, \mathrm{m}), 3.44\left(3 \mathrm{H}, \mathrm{s}, \mathrm{OCH}_{3}\right), 3.8-4.1(3 \mathrm{H}$, $\mathrm{m}), 4.90(1 \mathrm{H}, \mathrm{s}, \mathrm{OH})$, and $7.3-7.8(4 \mathrm{H}, \mathrm{m}) ; \mathrm{v}_{\max }(\mathrm{KBr}) 3280$ $(\mathrm{OH}), 2910,1670$ (amide), 1474, $1420,1288,1102,764$, and $702 \mathrm{~cm}^{-1} ; m / z(20 \mathrm{eV}) 231\left(4, M^{+}-\mathrm{H}_{2} \mathrm{O}\right), 217(11), 200(3), 175$ (11), 174 (100), 173 (16), and 160 (15) (Found: C, 62.6; H, 6.0; N, 5.6. $\mathrm{C}_{13} \mathrm{H}_{15} \mathrm{NO}_{4}$ requires $\mathrm{C}, 62.6 ; \mathrm{H}, 6.1 ; \mathrm{N}, 5.6 \%$ ).

Acid Dehydration of Compounds (8a) and (9a).-A few drops of hydrochloric acid were added to a solution of $(\mathbf{8 a})(300 \mathrm{mg})$ in chloroform $(20 \mathrm{ml})$ and the solution was left overnight at room temperature. The solution was washed successively with saturated aqueous sodium hydrogen carbonate $(10 \mathrm{ml})$ and water $(10 \mathrm{ml})$, and dried $\left(\mathrm{MgSO}_{4}\right)$ and evaporated. Column chromatography of the residue over silica gel with dichloromethane as eluant to give (10a) $(260 \mathrm{mg}, 93 \%)$. Analogously, starting from $(9 a)(100 \mathrm{mg}),(10 a)$ was obtained in a yield of $73 \%$. 3,4-Dihydro-1-methoxymethyl-6H-isoindolo[1,2-c] [1,4]oxazin6-one (10a); m.p. $114-116^{\circ} \mathrm{C}$ (from hexane); $\delta_{\mathrm{H}}\left(\mathrm{CDCl}_{3}\right) 3.44(3$ $\left.\mathrm{H}, \mathrm{s}, \mathrm{OCH}_{3}\right), 3.9-4.1(2 \mathrm{H}, \mathrm{m}), 4.2-4.4(2 \mathrm{H}, \mathrm{m}), 4.40(2 \mathrm{H}, \mathrm{s}$, $\left.\mathrm{CH}_{2} \mathrm{OMe}\right)$, and 7.3-8.0 (4 H, m, ArH); $v_{\text {max. }}(\mathrm{KBr}) 1708$ (amide), 1 680, 1 664, $1354,1226,1$ 168, 1091,1050 , and 761 $\mathrm{cm}^{-1} ; m / z(20 \mathrm{eV}) 231\left(85, M^{+}\right), 200\left(100, M^{+}-\mathrm{OMe}\right)$, and 186 (22, $M^{+}-\mathrm{CH}_{2} \mathrm{OMe}$ ) (Found: $\mathrm{C}, 67.8 ; \mathrm{H}, 5.9 ; \mathrm{N}, 6.1$. $\mathrm{C}_{13} \mathrm{H}_{13} \mathrm{NO}_{3}$ requires $\mathrm{C}, 67.5 ; \mathrm{H}, 5.7 ; \mathrm{N}, 6.1 \%$ ).

Irradiation of Compound (1d) in Ethanol.-A solution of (1d) $(500 \mathrm{mg})$ in ethanol $(400 \mathrm{ml})$ was irradiated and the product subjected to column chromatography over silica gel with ether as eluant to give (8b) (43\%) and (9b) (19\%).

$1 \alpha$-Ethoxymethyl-10b $\beta$-hydroxy-1,3,4,10b-tetrahydro- $6 \mathrm{H}$ isoindolo $[1,2-\mathrm{c}][1,4]$ oxazin-6-one $(\mathbf{8 b}), \quad$ m.p. $\quad 162-163.5^{\circ} \mathrm{C}$ (from ethanol); $\delta_{\mathrm{H}}\left(\mathrm{CDCl}_{3}\right) 0.89\left(3 \mathrm{H}, \mathrm{t}, J_{1.2} 7 \mathrm{~Hz}, \mathrm{OCH}_{2} \mathrm{CH}_{3}\right)$, $2.95\left(2 \mathrm{H}, \mathrm{q}, J_{1.2} 7 \mathrm{~Hz}, \mathrm{OCH}_{2} \mathrm{Me}\right), 2.8-3.0(1 \mathrm{H}, \mathrm{m}), 4.19(1 \mathrm{H}$, dd, $\left.J_{1,2} 6 \mathrm{~Hz}, J_{\mathrm{AB}} 11 \mathrm{~Hz}, \mathrm{CH}_{2} \mathrm{OEt}\right), 3.5-5.0(4 \mathrm{H}, \mathrm{m}), 4.39(1 \mathrm{H}$, $\left.\mathrm{t}, J_{1,2} 6 \mathrm{~Hz}, \mathrm{OCHCH}{ }_{2} \mathrm{OEt}\right), 4.71(1 \mathrm{H}, \mathrm{s}, \mathrm{OH})$, and $7.2-7.7(4 \mathrm{H}$, $\mathrm{m}, \mathrm{ArH}) ; v_{\max }(\mathrm{KBr}) 3240(\mathrm{OH}), 1688$ (amide), 1418,1096 , $1054,994,769,700 \mathrm{~cm}^{-1} ; m / z(20 \mathrm{eV}) 245$ (11), $217(15), 200(11)$,
175 (13), $174(100), 173(18)$, and $160(18)$ (Found: C, 64.1; H, 6.4; $\mathrm{N}, 5.3 . \mathrm{C}_{14} \mathrm{H}_{17} \mathrm{NO}_{4}$ requires $\mathrm{C}, 63.9 ; \mathrm{H}, 6.5 ; \mathrm{N}, 5.3 \%$ ).

$1 \beta$-Ethoxymethyl-10ß-hydroxy-1,3,4,10b-tetrahydro- $6 \mathrm{H}$-isoindolo $[1,2-\mathrm{c}][1,4]$ oxazin-6-one (9b), m.p. $133-135^{\circ} \mathrm{C}$ (from ethanol); $\delta_{\mathrm{H}}\left(\mathrm{CDCl}_{3}\right) 0.92\left(3 \mathrm{H}, \mathrm{t}, J_{1,2} 7 \mathrm{~Hz}, \mathrm{OCH}_{2} \mathrm{CH}_{3}\right), 2.7-$ $4.4(10 \mathrm{H}, \mathrm{m})$, and $7.3-7.9(4 \mathrm{H}, \mathrm{m}, \mathrm{ArH}) ; m / z(20 \mathrm{eV}) 245(5)$, 217 (10), $200(10), 175(15), 174(100), 173(15)$, and $160(20)$ (Found: $\mathrm{C}, 63.8 ; \mathrm{H}, 6.6 ; \mathrm{N}, 5.3 . \mathrm{C}_{14} \mathrm{H}_{17} \mathrm{NO}_{4}$ requires $\mathrm{C}, 63.9 ; \mathrm{H}$, $6.5 ; \mathrm{N}, 5.3 \%$ ).

Acid Dehydration of Compounds (8b) and (9b).-A few drops of hydrochloric acid were added to a solution of $(8 \mathrm{~b})(250 \mathrm{mg})$ in chloroform $(20 \mathrm{ml})$ and the solution was left overnight at room temperature. The solution was washed successively with saturated aqueous hydrogen carbonate $(10 \mathrm{ml})$ and water $(10$ $\mathrm{ml})$, dried $\left(\mathrm{MgSO}_{4}\right)$, and then evaporated. Column chromatography of the residue over silica gel with dichloromethane as eluant gave (10b) $(216 \mathrm{mg}, 93 \%)$.

In an n.m.r. tube, a drop of $\left[{ }^{2} \mathrm{H}\right]$ hydrochloric acid was added to a solution of $(\mathbf{9 b})$ in $\left[{ }^{2} \mathrm{H}\right]$ chloroform. The reaction was followed by ${ }^{1} \mathrm{H}$ n.m.r. spectroscopy. The production of (10b) was observed in a similar fashion.

3,4-Dihydro-1-ethoxymethyl-6H-isoindolo $[1,2-\mathrm{c}][1,4]$ oxazin6-one $(10 \mathrm{~b})$, m.p. $105.5-106.5^{\circ} \mathrm{C}$ (from hexane); $\delta_{\mathrm{H}}\left(\mathrm{CDCl}_{3}\right.$ ) $1.26\left(3 \mathrm{H}, \mathrm{t}, J_{1.2} 8 \mathrm{~Hz}, \mathrm{OCH}_{2} \mathrm{CH}_{3}\right), 3.66\left(2 \mathrm{H}, \mathrm{q}, J_{1.2} 8 \mathrm{~Hz}\right.$, $\left.\mathrm{OCH}_{2} \mathrm{Me}\right), 3.9-4.1(2 \mathrm{H}, \mathrm{m}), 4.2-4.4(2 \mathrm{H}, \mathrm{m}), 4.48(2 \mathrm{H}, \mathrm{s}$, $\mathrm{CH}_{2} \mathrm{OEt}$ ), and 7.2-8.0 (4 H, m, ArH); $v_{\text {max. }}(\mathrm{KBr}) 1706$ (amide), $1354,1288,1216,1091$, and $761 \mathrm{~cm}^{-1} ; m / z(20 \mathrm{eV}) 245$ (73, $M^{+}$), and $200\left(100, M^{+}-\mathrm{OEt}\right.$ ) (Found: C, 68.5; H, 6.1; N, 5.7. $\mathrm{C}_{14} \mathrm{H}_{15} \mathrm{NO}_{3}$ requires $\mathrm{C}, 68.6 ; \mathrm{H}, 6.2 ; \mathrm{N}, 5.7 \%$ ).

Oxidation of Compound (10b).-Chromium trioxide (300 mg) was added to a solution of $(10 \mathrm{~b})(200 \mathrm{mg})$ in acetic acid $(20 \mathrm{ml})$ and the mixture refluxed for $2 \mathrm{~h}$. After cooling the solution was poured into water $(50 \mathrm{ml})$ and extracted with chloroform $(3 \times$ $200 \mathrm{ml}$ ). The combined extracts were washed several times with saturated aqueous sodium hydrogen carbonate and finally with water, dried $\left(\mathrm{MgSO}_{4}\right)$, and evaporated. The residue was purified by column chromatography over silica gel with etherdichloromethane as eluant to give $N$-(2-ethoxyacetoxyethyl)phthalimide (11) (148 mg, 65\%), m.p. $52-53{ }^{\circ} \mathrm{C}$ (from hexane); $\delta_{\mathrm{H}}\left(\mathrm{CDCl}_{3}\right) 1.20\left(3 \mathrm{H}, \mathrm{t}, \mathrm{OCH}_{2} \mathrm{CH}_{3}\right) 3.54\left(2 \mathrm{H}, \mathrm{q}, \mathrm{OCH}_{2} \mathrm{Me}\right)$, $3.94\left(2 \mathrm{H}, \mathrm{t}, \mathrm{NCH}_{2}\right), 4.36\left(2 \mathrm{H}, \mathrm{t}, \mathrm{CH}_{2} \mathrm{OCO}\right)$, and $7.5-7.9(4 \mathrm{H}$, $\mathrm{m}, \mathrm{ArH}) ; v_{\max }(\mathrm{KBr}) 1770,1715$ (imide), 1742 (ester), 1428 , $1392,1302,1195,980$, and $718 \mathrm{~cm}^{-1} ; m / z(20 \mathrm{eV}) 233(39), 175$ (17), 174 (100), 173 (42), 160 (29), and 59 (36) (Found: C, 60.8; H, $5.5 ; \mathrm{N}, 5.3 . \mathrm{C}_{14} \mathrm{H}_{15} \mathrm{NO}_{5}$ requires $\mathrm{C}, 60.6 ; \mathrm{H}, 5.5 ; \mathrm{N}, 5.1 \%$ ).

Alternative Synthesis of Compound (11).-A solution of $N-(2-$ hydroxyethyl)phthalimide $(177 \mathrm{mg}),{ }^{19}$ of ethoxyacetic acid (104 $\mathrm{mg}$ ), and dicyclohexylcarbodi-imide (DCC) (240 mg) in acetonitrile $(20 \mathrm{ml})$ was refluxed for $12 \mathrm{~h}$. After evaporation of the solvent, column chromatography of the residue over silica gel with ether-dichloromethane $(1: 1)$ as eluant gave (11) (131 $\mathrm{mg}, 47 \%$ ).

Irradiation of cis-(1e) and trans-(1e) in Acetonitrile.--A solution of cis- $(1 \mathrm{e})(220 \mathrm{mg})$ in acetonitrile $(25 \mathrm{ml})$ was irradiated for $c a .8$ days. Column chromatography of the residue over silica gel with ether as eluant gave the unchanged imides cis-(1e) and trans-(1e) $(100 \mathrm{mg})$ and a mixture of cis-(2e) and trans-(2e) $(54 \mathrm{mg}, 45 \%)$. The mixture of the products was separated by h.p.l.c. ( $\mu$-Porasil preparative) with chloroform-nhexane $(3: 1)$ as eluant.

Solutions of cis-(1e) and trans-(1e) $(50 \mathrm{mg})$ in acetonitrile (25 $\mathrm{ml}$ ) were irradiated. The reactions were followed by the h.p.l.c. ( $\mu$-Porasil). The results are shown in the text.

1,2,3,10,11,11a-Hexahydro-11-exo-methyl-5H-pyrrolo- 
[1,2-b][2]benzazepine-5,10-dione, cis-(2e), $\delta_{\mathrm{H}}\left(\mathrm{CDCl}_{3}\right) \quad 1.29$ $\left(3 \mathrm{H}, \mathrm{d}, J_{1.2} 8 \mathrm{~Hz}, M e\right), 2.0(4 \mathrm{H}, \mathrm{m}), 2.70\left(1 \mathrm{H}, \mathrm{dq}, J_{1.2} 2,8 \mathrm{~Hz}\right)$, $3.6(3 \mathrm{H}, \mathrm{m})$, and $7.4-8.0(4 \mathrm{H}, \mathrm{m}, \mathrm{ArH})$.

1,2,3,10,11,11a-Hexahydro-11-exo-methyl-5H-pyrrolo[1,2-b][2]benzazepine-5,10-dione, trans-(2e), $\delta_{\mathrm{H}}\left(\mathrm{CDCl}_{3}\right) 1.14$ $\left(3 \mathrm{H}, \mathrm{d}, J_{1,2} 8 \mathrm{~Hz}, M e\right), 1.93(4 \mathrm{H}, \mathrm{m}), 2.75\left(1 \mathrm{H}, \mathrm{dq}, J_{1,2} 8,12 \mathrm{~Hz}\right)$, $3.6(3 \mathrm{H}, \mathrm{m})$, and $7.4-8.0(4 \mathrm{H}, \mathrm{m}, \mathrm{ArH})$.

\section{Acknowledgements}

We are indebted to Professor Masao Kakudo, Dr. Nobuo Tanaka, and Mr. Kenichi Sakaguchi of Osaka University (the Institute for Protein Research), and Dr. Keiichi Fukuyama of Tottori University for $X$-ray diffraction analysis.

\section{References}

1 (a) Y. Kanaoka, Acc. Chem. Res., 1978, 11, 407; (b) P. H. Mazzocchi, in 'Organic Photochemistry,' ed. A. Padwa, Marcel Dekker, New York, 1981, vol. 5, p. 421.

2 (a) K. Maruyama and Y. Kubo, J. Org. Chem., 1977, 42, 3215; (b) K. Maruyama, T. Ogawa, and Y. Kubo, Chem. Lett., 1978, 1107.

3 (a) K. Maruyama and Y. Kubo, J. Org. Chem., 1981, 46, 3612; (b) K. Maruyama, Y. Kubo, M. Machida, K. Oda, Y. Kanaoka, and K. Fukuyama, J. Org. Chem., 1978, 43, 2303.

4 (a) K. Maruyama and Y. Kubo, J. Am. Chem. Soc., 1978, 100, 7772; (b) M. Machida, K. Oda, K. Maruyama, Y. Kubo, and Y. Kanaoka, Heterocycles, 1980, 14, 779.
5 K. Maruyama and Y. Kubo, Chem. Lett., 1978, 769.

6 Y. Kanaoka, Y. Migita, K. Koyama, Y. Sato, H. Nakai, and T. Mizoguchi, Tetrahedron Lett., 1973, 1193.

7 P. H. Mazzocchi, S. Minamikawa, and P. Wilson, J. Org. Chem., 1979, 44, 1186.

8 P. H. Mazzocchi, M. Bowen, and N. Narian, J. Am. Chem. Soc., 1977, 99, 7063.

9 (a) P. H. Mazzocchi, S. Minamikawa, and M. Bowen, J. Org. Chem., $1978,43,3079 ;(b)$ Y. Kanaoka, K. Yoshida, and Y. Hatanaka, J. Org. Chem., 1979, 44, 664

10 P. H. Mazzocchi, S. Minamikawa, and H. Bowen, Heterocycles, 1978, 9, 1713.

11 P. H. Mazzocchi, S. Minamikawa, P. Wilson, M. Bowen, and N. Narian, J. Org. Chem., 1981, 46, 4846.

12 P. H. Mazzocchi, F. Khachik, P. Wilson, and R. Highet, J. Am. Chem. Soc., 1981, 103, 6498

13 (a) S. R. Kurowsky and H. Morrison, J. Am. Chem. Soc., 1972, 94, 507; (b) H. Morrison, V. Tisdale, P. J. Wagner, and K.-C. Liu, J. Am. Chem. Soc., 1975, 97, 7189.

14 J. J. McCullough, W. K. MacInnis, C. J. L. Lock, and R. Faggiani, J. Am. Chem. Soc., 1980, 102, 7780.

15 W. Kirmse and D. Grassmann, Chem. Ber., 1955, 99, 1746.

16 O. Riobe and H. Cottin, C. R. Acad. Sci., 1955, 240, 1783.

17 G. W. Pucher and T. B. Johnson, J. Am. Chem. Soc., 1922, 44, 817.

18 L. Crombie and S. H. Happer, J. Chem. Soc., 1950, 1707.

19 T. O. Soine and M. R. Buchdahl, Org. Synth., Coll. Vol. 4, 1963, 106.

Received 29th August 1985; Paper 4/1484 